Studies in African Linguistics

Volume 33, Number 1, 2004

\title{
A DIACHRONIC ANALYSIS OF NDUT VOWEL HARMONY*
}

\author{
Ursula Drolc \\ University of Cologne
}

\begin{abstract}
Ndut is spoken in Senegal and belongs to the Cangin languages, a subgroup of the (West-) Atlantic languages (Sapir 1971). Unlike the other Cangin languages Noon, Laala and Saafi, Ndut, as well as closely related Palor, exhibits apparently bidirectional vowel harmony. However, a phonological analysis suggests that there are two independent phenomena that have to be kept separate: regressive vowel assimilation, which is probably a very archaic feature of the Atlantic languages, and progressive root-controlled harmony, which may be a contactinduced innovation. In Senegal, the dominant language is Wolof, a Senegambian language that is part of a different subgroup of Atlantic languages. As Wolof is the major medium of interethnic communication, most Ndut speakers are Wolofbilingual. Consequently, contact-induced language changes are likely to appear in Ndut.
\end{abstract}

\section{Outline}

This paper attempts a diachronic analysis of the vowel harmony system of Ndut. Two different types of vowel harmony have to be distinguished: progressive rootcontrolled harmony, and regressive vowel harmony with [+ATR] as the dominant feature. Both processes are examined in detail and hypotheses regarding their origin are put forward. The diachronic analysis includes the reconstruction of the Proto-Cangin vowel system. Finally, there is a comparison of Ndut and Wolof

* I would like to thank David Odden and an anonymous reviewer for their valuable comments on an earlier version of this paper. I use the following grammatical abbreviations: RV $=$ reversive CS $=$ causative; imp. $=$ imperative, pl. $=$ plural; $\mathrm{sg} .=$ singular. 
vowel harmony, and arguments are given to support the claim that progressive harmony is a contact-induced innovation.

Both languages, Ndut and Wolof, are classified as being part of the Northern Branch of the (West-)Atlantic languages. They belong to different subgroups: Wolof to the Senegambian languages and Ndut to the Cangin languages. The genetic relationship between these language groups is not very close.

\section{Table 1: Language Classification: (West) Atlantic (Sapir 1971: 48)}

I. Northern Branch:
A. Sénégal Languages: Wolof, Seereer, Pulaar
B. Cangin Languages: Ndut (Nd), Palor (P)
Saafi (S)
Noon (N), Laala (L)
C. Bak Languages
D. Eastern-Sénégal-Portuguese-Guinea Languages
E. Nalu, Mbulungish

According to the lexicostatistical analysis of Sapir (1971: 47), the maximum score of common vocabulary between the two language groups is $18 \%$. Atlantic languages share several typological features with Niger-Congo languages but their genetic unity is far from proven. Sapir (1971) and other scholars seriously question whether the different sub-groups of Atlantic languages are more closely related to each other than to other Niger-Congo languages:

Granted certain typological features common throughout, such as noun class systems and verbal extension suffixes, there is little that distinguishes the entire group in any obvious way. [p. 46]

\section{Data and Fieldwork}

Fieldwork was conducted in Senegal from January to March 2001 and from February to April 2002. The original purpose was to collect data for a comparative analysis of the five Cangin languages. Progressive vowel harmony occurs only in the languages Ndut and Palor, which have a high degree of mutual intelligibility. 
To investigate this in more detail, data of Ndut were collected. ${ }^{1}$ Five speakers ( 3 male and 2 female) were recorded. For each vowel a single word was recorded ten times and repeated once in a sentence. Various vowels involved in progressive vowel harmony and regressive vowel raising were also included. The data were recorded by a Sharp-Mini-Disc Recorder (ND-MT877H). Previous descriptions of the Cangin languages were included in the data base: the Ph. D. thesis on Palor by D'Alton (1987: 92, 142-143), the Ph. D. thesis on Noon by Soukka (2000: 57, 162f.), and the master's thesis on Ndut by Morgan (1996: 15). The rest of the data for Ndut $(\mathrm{Nd})$, Laala (L) and Saafi (S) are from my own material.

\section{Vowel Harmony in Ndut}

In the Ndut vowel inventory, both length and [ATR] (advanced tongue root) are distinctive. The [-ATR] vowels outnumber the [+ATR] vowels. The very rare [+ATR] vowels $[\partial$, əə] and [e, ee] appear to be secondary vowels resulting from regressive assimilation, as will be shown below. The central vowel [ə] is the [+ATR] counterpart of both [0] and the low vowel [a].

(1) Ndut vowels

\begin{tabular}{|c|c|c|c|}
\hline [-ATF & & {$[+\mathrm{AT}$} & \\
\hline I II & $U \quad U U$ & $\mathrm{i}$ ii & $\mathrm{u}$ \\
\hline$\varepsilon \varepsilon$ & 0 oง & e ee & o \\
\hline a aa & & Ә & \\
\hline
\end{tabular}

Vowel harmony is a widespread phonological phenomenon in Africa. In vowel harmony systems, all (or a subset of) vowels in a defined domain such as the word or stem share a given distinctive feature, e.g. [ \pm ATR]. According to their spreading behaviour under affixation, two vowel harmony systems can be distinguished: dominant harmony systems, and root-controlled systems (cf. Clements 2000: 135). In dominant harmony systems, a set of vowels with a specific feature (usually [+ATR]) is dominant and triggers the harmonisation of the other vowels in both roots and affixes. In root-controlled systems, the vowels of the root remain stable and the vowels of affixes assimilate to the root vowels. According to Stewart (1983), most of the dominant harmony systems can be found

\footnotetext{
1 The data had been collected under the advice of Prof. Didier Demolin of the phonetic institute of the Universite libre de Bruxelles, to whom I owe my greatest thanks. A detailed acoustic analysis of the vowels is intended for the future.
} 
in Eastern Africa, whereas most of the root-controlled systems occur in Western Africa. Contrary to this previously assumed geographic distribution of vowel harmony types, Dimmendaal (2002) observes both root-control and feature dominance in the evolution of harmony systems of the Eastern African Nilotic languages. In the Western African language Ndut, both types of vowel harmony apparently occur. As the spreading processes may be both regressive and progressive, Diop Diagne (1989: 19) considers Ndut vowel harmony to be bidirectional. Morgan (1996: 16) states that vowel harmony in Ndut is completely regular. The bidirectional spreading of the dominant feature [+ATR] would leave neither disharmonic roots nor opaque or neutral vowels.

The following examples of the imperative paradigm in Ndut exemplify both phonological processes: root-controlled harmony of the alternating imperative singular suffix $-E$, dominant harmony triggered by the [+ATR] imperative plural suffix $-i$. In progressive root-controlled harmony, the stem or root vowel remains stable. The spreading direction is from left to right or from the stem to the affix. Regressive assimilation applies in the opposite direction, from right to left or from the suffix to the stem. The following table contains verb stems with various vowels of Ndut and their phonetic behaviour when both imperative suffixes are added. Because of the rare occurrence of the vowels [ə] and [e], only verb stems containing long vowels have been found. The verb stem [seen] is a loan word from Wolof.

(2) Imperative paradigm in Ndut

\begin{tabular}{|c|c|c|c|c|}
\hline Vowel & Stem & gloss & Imperative sg. & Imperative pl. \\
\hline $\mathrm{a}$ & [dap] & 'boucher' & {$[\mathrm{dap}-\varepsilon]$} & \\
\hline $\mathrm{a}:$ & [daap] & 'apposer' & [daap- $\varepsilon]$ & [dəəp-i] \\
\hline 0 & [wox] & 'garder' & {$[\mathrm{w} \partial \mathrm{x}-\varepsilon]$} & {$[\text { wox-i }]^{2}$} \\
\hline ๑: & [fool $]$ & 'sauter' & [fool- $\varepsilon]$ & [fool-i] \\
\hline$\varepsilon$ & {$[\varepsilon n]$} & 'porter sur la tête' & {$[\varepsilon n-\varepsilon]$} & [en-i] \\
\hline$\varepsilon:$ & [pecn] & 'causer' & {$[p \varepsilon \varepsilon n-\varepsilon]$} & [peen-i] \\
\hline ə: & [dəək] & 'appeler' & [dəək-e] & [dəək-i] \\
\hline e: & [seen] & 'aperçevoir' & [seen-e] & [seen-i] \\
\hline U: & [tuul] & 'cracher' & [tuul- $\varepsilon]$ & [tuul-i] \\
\hline $\mathrm{u}$ & [pun] & 'voler' & [pud-e] & [pud-i] \\
\hline I: & {$\left[\mathrm{t}_{\mathrm{l}} \mathrm{ll}\right]$} & 'répondre' & {$[\mathrm{tl} l \mathrm{l}-\varepsilon]$} & {$\left[\mathrm{t}_{11} \mathrm{l}-\mathrm{i}\right]$} \\
\hline i: & [pii] & 'ramasser' & [pii?-e] & [pii?-i] \\
\hline
\end{tabular}

2 This might almost be heard as [wux-i]. 
In progressive harmony, the verb stem remains unaltered. The [ATR] value of the verb stem determines the realisation of the suffix $-E$. A [+ATR] vowel in the verb stem implies the surface realisation [e]. The suffix surfaces as $[\varepsilon]$ when the verb stem contains a [-ATR] vowel. Because of this suffix-determining behaviour of the stem vowels, the [ATR] value appears to be an underlying feature of the lexicon. In this case root faithfulness would prevail over [ATR] alignment, in OT terms.

However, root faithfulness does not dominate ATR alignment when the imperative plural suffix $-i$ is attached. Leftward [ATR] alignment prevails over root faithfulness when regressive assimilation applies to the stem vowels. However, not all stem vowels are involved in this alternation. Only the non-high [-ATR] vowels $[a, o, \varepsilon]$ are altered. There is no alternation of the [+ATR] vowels $[ə, \mathrm{e}, \mathrm{i}, \mathrm{u}]$, and also, interestingly, the high [-ATR] vowels [1] and [u] remain unaltered. Like umlaut phenomena, regressive vowel raising is triggered by a following suffix with the high [+ATR] vowel [i]. Five different suffixes with triggering [i] can be found in Ndut (see (30) below) but to the best of my knowledge there are no triggering suffixes containing the high vowel $[\mathrm{u}]$. The high [-ATR] vowels $[\mathrm{I}]$ and $[\mathrm{U}]$ fail to trigger regressive harmony, and they undergo progressive harmony. There are no suffixes with underlying [+ATR] non-high vowels [e] and [o], so these vowels cannot be shown to cause harmony. The direction of the spreading is from left to right. Articulatorily, this raising process is motivated as anticipation of the high tongue-body position that is required for the pronunciation of the following high vowel. The result of this process is the emergence of raised surface vowels with the feature [+ATR]. As formalised in (3), high vowels remain unaltered.

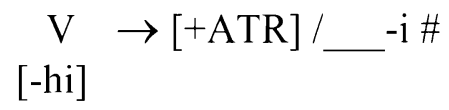

To define the phonological domain of this vowel raising process, verbs consisting of more than one syllable are required. Unfortunately, most of the verb roots in Ndut are monosyllabic. One polysyllabic verb is the derived verb sem-anta-l-sx 'spy'. The imperative plural suffix $-i$ causes assimilation only of the preceding vowel, as in the following example where there is coalescence of the last two syllables, resulting in a lengthened vowel. This finding suggests that the domain of the vowel raising process is restricted to the preceding syllable. Another interpretation of this phenomenon is that only high [+ATR] vowels transmit regressive 
harmony. According to this phonological condition, the derived vowel [ə] would block the reapplication of harmony.

(4) sem-anta-l-ox-i $\rightarrow$ semantəlii 'spy! (imp. pl)'

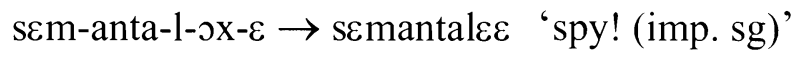

\section{Reconstruction of the Proto-Cangin Vowel System}

A diachronic analyis attempts to trace language developments in order to reconstruct the common proto-language of genetically related languages. The Cangin languages form such a genetic unit. For a better understanding of the reconstruction of the proto-Cangin vowel system, an overview of the synchronic vowel inventories of the Cangin languages is given below. The data for Saafi and Laala come from my own field notes.

(5) Saafi

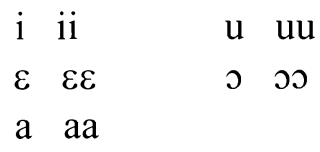

(6) Palor (D'Alton 1987:73)

$\begin{array}{llll}{[-\mathrm{ATR}]} & & {[+\mathrm{ATR}]} & \\ \mathrm{I} & \mathrm{U} & \mathrm{i} & \mathrm{u} \\ \varepsilon & 0 & \\ \mathrm{a} & & \text { (e) }\end{array}$

(7) Laala [-ATR] [+ATR]
I II
U UU
i ii
$\mathrm{u} \mathrm{uu}$
$\varepsilon \quad \varepsilon \varepsilon$
$0 \quad 00$
a aa
ว วว

(8) Noon (Soukka 2000:33)

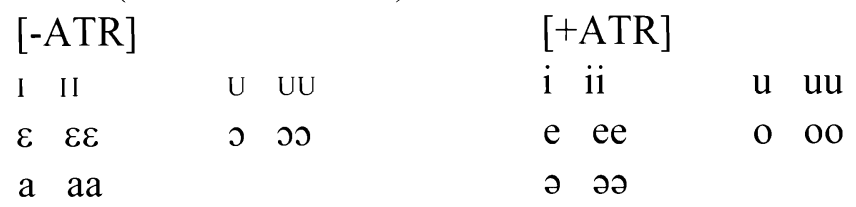


Most of the Cangin languages distinguish at least eight different vowels. Their vowel inventories include a central vowel and exhibit a contrast between high $[-A T R]([\mathrm{I}, \mathrm{u}])$ and $[+\mathrm{ATR}]$ vowels $([\mathrm{i}, \mathrm{u}])$. Only Saafi has a five vowel system with neither a central vowel nor a phonemic [ATR] contrast between high vowels. The obvious merger of the high vowels will be marked in the tables by the majuscule letters I and U.

There are two closely related language pairs: Noon/Laala and Ndut/Palor. In the lexicostatistic word comparison conducted by Williams (1994: 51) the languages of each pair have more than $80 \%$ shared vocabulary. The major differences in the vowel inventories of these closely related languages appear to be mostly due to the different phonemic interpretations of the authors. In most of the Cangin languages, vowel length is a distinctive feature, although D'Alton (1987) considers long vowels to be biphonemic combinations of two short vowels. However, the fact that phonetically long vowels do occur in Palor, and the regular sound correspondence to other long vowels in cognates of the other Cangin languages suggest that long vowels should also be given phonemic status in Palor. A phonetic difference between Palor and the other languages is the realisation of the central vowel as $[\mathfrak{e}]$. The major difference between the vowel inventories in Noon and Laala lies in the phonemic status of the [+ATR] vowels [e] and [o], which occur very rarely in both languages. In these rare occurrences they may be identified as allophones of $/ \varepsilon /$ and $/ \mathrm{J} /$ resulting from regressive assimilation as shown below.

The reconstruction of the following proto-Cangin vowel system (9) is based on the comparative evidence given below and in the appendix.

$\begin{array}{llll}\text { Proto-Cangin Vowel System } & \\ \text { [-ATR] } & & {[+\mathrm{ATR}]} & \\ \left(*_{\mathrm{I}}\right) *_{\mathrm{II}} & \left(*_{\mathrm{U}}\right) *_{\mathrm{UU}} & *_{\mathrm{i}} *_{\mathrm{ii}} & *_{\mathrm{u}} *_{\mathrm{uu}} \\ *_{\varepsilon} *_{\varepsilon \varepsilon} & *_{\mathrm{o}} *_{\mathrm{o}} & *_{\mathrm{e}}\left(*_{\mathrm{ee}}\right) & *_{\mathrm{o}}\left(*_{\mathrm{oo}}\right) \\ *_{\mathrm{a}} *_{\mathrm{aa}} & & & \end{array}$

The Proto-Cangin vowel system consists of seven to nine long and short vowels. For the sake of presenting a balanced vowel system (cf. Crowley 1994: 98), some proto-phonemes are in parentheses, indicating a lack of convincing comparative evidence. The short and long vowels $[\mathrm{a}, \mathrm{\jmath}, \varepsilon, \mathrm{i}, \mathrm{u}]$ exhibit relative sound stability in their diachronic development. Each of these vowels occurs in at least four cognates (see Appendix). There are regular sound correspondences of $[\varepsilon] \sim[\mathrm{I}]$ and $[\mathrm{o}] \sim[\mathrm{U}]$ which lead conclusively to the reconstruction of a phonemic 
[ATR] contrast between mid vowels. These reconstructed mid [+ATR] vowels have no reflexes in the daughter languages, which exhibit no [ATR] contrast between mid vowels. However, comparative data containing high [-ATR] vowels is scarce. No more than two cognate words occur in my data $(10,11)$.

(10) Short U

$\begin{array}{llllll}\text { Ndut } & \text { Palor } & \text { Saafi } & \text { Laala } & \text { Noon } & \\ \text { bux } & \text { bux } & \text { 6Ux } & \text { bu? } & \text { baay } & \text { 'dog', } \\ \text { fu } & \text { fu } & \text { fU } & \text { fu } & \text { fu } & \text { '2sg.' }\end{array}$

(11) Short I

$\begin{array}{llllll}\text { Ndut } & \text { Palor } & \text { Saafi } & \text { Laala } & \text { Noon } & \\ \text { wic } & \text { wic } & \text { wic } & \text { wi? } & \text { wI? } & \text { 'horn' } \\ \text { nIf } & \text { jIf } & \text { jIf } & \text { jIf } & \text { jIf } & \text { 'blood' }\end{array}$

More common is the following pattern of sound correspondence. High [-ATR] vowels in Ndut and Palor correspond to mid [-ATR] vowels in Noon and Laala. In six cognate words the vowel [u] in Ndut and Palor corresponds to the vowel [0] in Noon and Laala. Similarly, there are regular sound correspondences between the front vowel [1] in Ndut and Palor and the mid vowel $[\varepsilon]$ in Noon and Laala. Saafi is posited as genetically intermediate between these two subgroups and shares either the high [-ATR] vowel [1] with Ndut and Palor or the mid vowel [0] with Noon and Laala.

(12) Sound correspondence U D

\begin{tabular}{|c|c|c|c|c|c|}
\hline $\begin{array}{l}\text { Ndut } \\
\text { nuf }\end{array}$ & $\begin{array}{l}\text { Palor } \\
\text { nuf }\end{array}$ & $\begin{array}{l}\text { Saafi } \\
\text { nof }\end{array}$ & $\begin{array}{l}\text { Laala } \\
\text { nof }\end{array}$ & $\begin{array}{l}\text { Noon } \\
\text { nof }\end{array}$ & ‘ear’ \\
\hline xul & $\mathrm{xul}$ & xor & xol & xol & 'star' \\
\hline yux & yux & yox & $y 0 x$ & yox & 'bone' \\
\hline $\operatorname{lux}$ & lux & roxəy & loy & ləхэy (loy) & 'short' \\
\hline nun & nuy & $\mathrm{nUy}$ & non & noy & 'hole' \\
\hline & ut & xUt? & xoor & хоว? & 'long' \\
\hline
\end{tabular}


(13) Sound correspondence $I \sim \varepsilon$

\begin{tabular}{|c|c|c|c|c|c|}
\hline Ndut & Palor & Saafi & Laala & Noon & \\
\hline (tal-) kılık & tal-kılık & kIdIk & $\mathrm{k} \varepsilon \mathrm{d} \varepsilon \mathrm{k}$ & $\mathrm{k} \varepsilon \mathrm{d} \varepsilon \mathrm{k}$ & 'tree' \\
\hline & din & dIIn & $d \varepsilon n$ & $d \varepsilon \mathrm{n}$ & 'louse' \\
\hline misip & misip & mIsIp & mesıp & $m \varepsilon s ı p$ & 'sauce' \\
\hline misik & miskat & mIsIk & -mesık & -mEsık & 'suffer' \\
\hline
\end{tabular}

These regular sound correspondences indicate a vowel shift in the development of the daughter languages. The major problem is to determine the direction of the sound change. Theoretically, three different hypotheses are possible:

I. The mid [-ATR] vowels of Noon and Laala are retentions of the proto-phonemes $*[\varepsilon]$ and $*[0]$. Vowel shift occurs in Ndut and Palor:

$$
*_{\varepsilon}>_{1}(\mathrm{Nd}, \mathrm{P}) \quad *_{\mathrm{J}}>_{\mathrm{U}}(\mathrm{Nd}, \mathrm{P})
$$

II. The high [-ATR] vowels in Ndut and Palor are retentions of the proto-phonemes $*[\mathrm{I}]$ and $*[\mathrm{U}]$. In Noon and Laala $*[\mathrm{I}]$ and $*[\mathrm{U}]$ shift to $[\varepsilon]$ and $[0]$ and merge with the already existing mid vowels:

$$
*_{\mathrm{I}}>\varepsilon(\mathrm{N}, \mathrm{L}) \quad *_{\mathrm{U}}>\rho(\mathrm{N}, \mathrm{L})
$$

III. The proto-language contains mid [+ATR] vowels *[e] and *[o] that shift either to [I] and [U] in Ndut and Palor or to [E] and [o] in Noon and Laala:

$$
\begin{array}{ll}
*_{\mathrm{e}}>_{\mathrm{I}}(\mathrm{Nd}, \mathrm{P}) & *_{\mathrm{e}}>\varepsilon(\mathrm{N}, \mathrm{L}) \\
*_{\mathrm{O}}>\mathrm{U}(\mathrm{Nd}, \mathrm{P}) & *_{\mathrm{O}}>\rho(\mathrm{N}, \mathrm{L})
\end{array}
$$

The major argument against the first hypothesis is the strong evidence of sound stability of the [-ATR] mid vowels $[\varepsilon, \varepsilon \varepsilon\lrcorner, 00$,$] in the diachronic development.$ The comparative wordlists (14-17) contain at least four cognate words for each mid [-ATR] vowel. Thus, a rule would be required to separate the shifting from the non-shifting mid vowels. By the standard theory of regularity of sound change, the reconstruction of both stable $[\varepsilon$ o $]$ and variable $[\varepsilon(\mathrm{I}) \rho(\mathrm{U})]$ as the same historical phoneme, without any rule conditioning, is not possible. 
(14) Short \&

\begin{tabular}{|c|c|c|c|c|c|}
\hline $\begin{array}{l}N d u t \\
6 \varepsilon 6\end{array}$ & $\begin{array}{l}\text { Palor } \\
\text { (kod) }\end{array}$ & $\begin{array}{l}\text { Saafi } \\
\text { (baay wf) }\end{array}$ & $\begin{array}{l}\text { Laala } \\
-6 \varepsilon 6\end{array}$ & $\begin{array}{l}\text { Noon } \\
-6 \varepsilon 6\end{array}$ & 'take' \\
\hline y\&n & yen & yecn & $(-$-уıр) & $-\mathrm{y} \varepsilon ?$ & 'push' \\
\hline yen & $y \varepsilon n$ & $\mathrm{j} \varepsilon \mathrm{n}$ & $-y \varepsilon n$ & $-y \varepsilon n$ & 'laugh' \\
\hline $\mathrm{k} \varepsilon \mathrm{l}$ & $\mathrm{k} \varepsilon \mathrm{l}$ & kerax & -kalax & $-k \varepsilon \operatorname{lox}$ & 'understand' \\
\hline
\end{tabular}

(15) Long $\varepsilon$

$\begin{array}{llllll}\text { Ndut } & \text { Palor } & \text { Saafi } & \text { Laala } & \text { Noon } & \\ \mathrm{k} \varepsilon \varepsilon \mathrm{n} & \mathrm{k} \varepsilon \varepsilon \mathrm{n} & \mathrm{k} \varepsilon \varepsilon \mathrm{n} & \mathrm{k} \varepsilon \varepsilon \mathrm{n} & \mathrm{k} \varepsilon \varepsilon \mathrm{n} & \text { 'fall' } \\ \mathrm{n} \varepsilon \varepsilon ? & \mathrm{n} \varepsilon ? & \mathrm{n} \varepsilon \mathrm{x} & \mathrm{n} \varepsilon \varepsilon \mathrm{x} & \mathrm{n} \varepsilon \varepsilon \mathrm{x} & \text { 'sleep' } \\ 6 \varepsilon \mathrm{t} & (\mathrm{x} \varepsilon \mathrm{y}) & \mathrm{w} \varepsilon \varepsilon \mathrm{S} & \mathrm{w} \varepsilon \varepsilon \mathrm{S} & \mathrm{w} \varepsilon \varepsilon \mathrm{S} & \text { 'throw' } \\ \mathrm{t} \varepsilon \varepsilon 6 & \mathrm{t} \varepsilon 6 & \mathrm{t} \varepsilon \varepsilon 6 & \mathrm{t} \varepsilon \mathrm{w}(\mathrm{ox}) & \mathrm{t} \varepsilon \varepsilon 6 & \text { 'show' } \\ \mathrm{y} \varepsilon \varepsilon \mathrm{k} & \mathrm{y} \varepsilon \mathrm{k} & \mathrm{y} \varepsilon \varepsilon \mathrm{k} & \mathrm{y} \varepsilon \varepsilon \mathrm{k} & \mathrm{y} \varepsilon \varepsilon \mathrm{k} & \text { 'sing' }\end{array}$

(16) Short o

\begin{tabular}{|c|c|c|c|c|c|}
\hline Ndut & Palor & Saafi & Laala & Noon & \\
\hline kot & kot & kot & kot & kot & 'foot, leg' \\
\hline lom & lom & rom & lom & & 'buy' \\
\hline to6 & to6 & top & fet?of- & tow & 'rain' \\
\hline gon & (yıınbos ) & (labrif) & gon & gong & 'snake' \\
\hline tI SOx & sox & disox & pesox & $\mathrm{p} \varepsilon \mathrm{sox}$ & 'seed' \\
\hline olon & ndoroy & mulun & molon & molon & 'round' \\
\hline nэp & nop & nэp & (bos) & nэp & 'rot' \\
\hline
\end{tabular}

(17) Long $\supset$

$\begin{array}{llllll}\text { Ndut } & \text { Palor } & \text { Saafi } & \text { Laala } & \text { Noon } & \\ \text { loo? } & \text { loo } & \text { rok } & \text { look } & \text { look } & \text { 'stomach' } \\ \text { dəon } & \text { doon } & \text { doon } & \text { don } & \text { doon } & \text { 'calf' } \\ \text { nood } & \text { nu(U)itE } & \text { nod } & \text { xot } & \text { xoot } & \text { 'deep' } \\ \text { sos } & \text { sos } & \text { soos } & \text { soosos } & \text { soos } & \text { 'cold' }\end{array}$

For the same reason, the second hypothesis that presumes the protophonemes $*[I]$ and $*[U]$ is also not very plausible. However, high [-ATR] vowels in cognate words of Noon and Laala occur very rarely. These rare occurrences could be retentions but they could also be due to internal borrowings. The area where the Cangin languages are spoken is relatively small in size. As the greatest 
distance does not exceed 100 miles, contact between speakers of different Cangin languages is likely to occur.

The following arguments support the third hypothesis. First, no rule would be required to explain apparent exceptions of sound change, such as the assumed borrowing of words containing / $\mathrm{u} /$ in Noon and Laala. Second, the principle of 'sound naturalness' indicates that the mid [+ATR] vowels /e o/ are phonetically closer to either of the vowel pairs $/ \varepsilon \mathrm{o} /$ and /I U/ than these two [-ATR] vowel pairs are to each other. Third, the reconstruction of [-ATR]/I U/ in Ndut and Palor as [+ATR] /e o/ in the proto-language could provide an explanation why these vowels are not affected by regressive harmony. However, this hypothesis would violate the principle of simplicity in historical reconstructions by reconstructing two proto-phonemes $*[\mathrm{e}]$ and $*[\mathrm{o}]$ that do not exist in most of the phonological systems of the daughter languages. The [+ATR] vowel [e] has phonemic status only in Ndut. Still, it remains a marginal sound that only occurs in very few words. Phonetically, the [+ATR] vowels may occur as allovariants of the mid vowels $[\varepsilon]$ and $[0]$ in Ndut, Laala and Noon.

Interestingly, the comparative lists give evidence for sound stability of the long high [-ATR] vowels. Only one cognate word exhibits the same sound correspondence of long vowels. Phonetically, the [-ATR] long vowels /II UU/ can barely be distinguished from the [+ATR] long vowels /ee oo/. Phonologically, the vowels in the words of Ndut and Palor given below can clearly be identified as [-ATR] vowels by the progressive harmony of the definite article.

\section{(18) Long I}

\begin{tabular}{|c|c|c|c|c|c|}
\hline $\begin{array}{l}N d u t \\
\text { tI I }\end{array}$ & $\begin{array}{l}\text { Palor } \\
\text { tII }\end{array}$ & $\begin{array}{l}\text { Saafi } \\
\text { tlk }\end{array}$ & $\begin{array}{l}\text { Laala } \\
\text { te\&k }\end{array}$ & $\begin{array}{l}\text { Noon } \\
\text { tE\&k }\end{array}$ & 'name' \\
\hline miss & miss & mIIs & mis & mils & 'milk' \\
\hline SIIk & sılk & sIIk & sılk & & 'cock, buck'3 \\
\hline yin & yin & yIIn & yiln & & 'guinea fowl' \\
\hline$y_{I I}$ & yill & yIIl & (kujab\&?) & & 'chick' \\
\hline
\end{tabular}

${ }^{3}$ The term means 'male animal' but its use is restricted to 'buck' and 'cock'. 
(19) Long vowel U

$\begin{array}{llllll}\text { Ndut } & \text { Palor } & \text { Saafi } & \text { Laala } & \text { Noon } & \\ \text { suul } & \text { suul } & \text { sUUr } & \text { suul } & & \text { 'vulture' } \\ \text { luuf } & \text { luuf } & \text { ndUUf } & \text { luuf } & \text { luuf } & \text { 'bush' } \\ \text { luun } & \text { luun } & \text { rUUn } & \text { luun } & & \text { 'witch' } \\ \text { (ndut) } & & \text { tUUy } & \text { tuy } & \text { tuuy } & \text { 'hut' } \\ \text { juus } & \text { juus } & \text { jUUs } & \text { jues } & & \text { 'darkness' }\end{array}$

No comparative data evidences stable sound development of Proto-Cangin * [e] to Ndut [e], but regressive harmony may account for the emergence of the [+ATR] mid vowel [e] in Ndut. If there is a second syllable in cognate words, it often contains a high vowel. In the word 'bug' there is sound correspondence of [e] with [ə] in Laala and [a] in Saafi. Interestingly, the same pattern of sound correspondence is exhibited in the Wolof loanword areen [areen] 'peanut' which appears to be a phonologically perfectly adapted loanword.

(20) Sound correspondences of e

\begin{tabular}{|c|c|c|c|c|}
\hline $\begin{array}{l}\text { Ndut } \\
\text { tepi } \\
\text { eren }\end{array}$ & 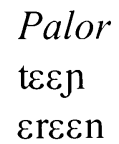 & $\begin{array}{l}\text { Saafi } \\
\text { taanin } \\
\text { aręn }\end{array}$ & $\begin{array}{l}\text { Laala } \\
\text { təəjiin } \\
\text { ərın }\end{array}$ & $\begin{array}{l}\text { 'bug' } \\
\text { 'peanut' }\end{array}$ \\
\hline
\end{tabular}

Similarly, regressive harmony accounts for the emergence of the central vowel. In the comparative wordlist (21) the central vowel may correspond to any non-high vowel in cognates of other Cangin languages. The occurrence of a high vowel in the second syllable in at least one of the cognate words suggests that the central vowel is the result of regressive harmony. Consequently, the central vowel was not included in the reconstruction.

(21) Sound correspondences of a / $\boldsymbol{E}$

$\begin{array}{llllll}\text { Ndut } & \text { Palor } & \text { Saafi } & \text { Laala } & \text { Noon } & \\ \text { pənis } & \text { penis } & \text { panIs } & \text { pənis } & & \text { 'horse' } \\ \text { cəəf } & \text { cəofu } & \text { caafU } & \text { cəfu } & \text { cəwul } & \text { 'fly' } \\ \text { səəgu } & & \text { saangU } & \text { səəgu } & & \text { 'shade' } \\ \text { fənuf } & \text { fen } & \text { fln } & \text { fen } & \text { fen } & \text { 'hair' }\end{array}$

${ }^{4}$ From Soukka (2000: 102). 


\section{Regressive Harmony}

Regressive vowel harmony is a common phenomenon in the Cangin languages. The following table gives an overview of suffixes triggering regressive harmony. Two of these suffixes occur in all Cangin languages. They are safe candidates for reconstruction: reversive ${ }^{*}-i s$ and causative ${ }^{*}-i d$. However, there is variation in the realisation of the adjectiviser and the experiential suffix even in the closely related language pairs Ndut/Palor and Noon/Laala. Note that in Noon and Laala there are also suffixes with the high vowel $u$ triggering regressive assimilation.

(22) Suffixes triggering regressive assimilation ${ }^{5}$

$\begin{array}{lll}\begin{array}{l}\text { Suffix } \\ \text {-is }\end{array} & \text { Function } & \text { Language } \\ \text {-id } & \text { reversive } & \text { N, L, Nd, P, S } \\ \text {-id/2 } & \text { causative } & \text { N, L, Nd, P, S } \\ \text {-id } & \text { adjectiviser } & \text { N, Nd (= P Id; L it/?) } \\ - \text { i } & \text { imperiential } & \text { Nd (=P Id) } \\ -\mathrm{Ci}: & \text { 1. pl. excl. } & \mathrm{Nd}, \mathrm{P} \\ -\mathrm{Cu}: & \text { 2. pl. } & \mathrm{N} \\ -\mathrm{Cu} & \text { 2. pl. } & \mathrm{L}\end{array}$

In Saafi, high [+ATR] and [-ATR] vowels merged. The missing contrast produced homophonous suffixes for the reversive $*_{-}$is and the repetitive $*_{-I S}$. Nevertheless, when affixing the reversive suffix -is there is regressive harmony applying only to mid vowels. The other vowels are not affected by regressive harmony:

Homophonous Suffixes in Saafi

$\begin{array}{lll}\text { Verb stem } & \text { Derived form } & \text { Reversive } \\ \text { tok 'attacher' } & \text { tok-Is } & \text { 'detacher' } \\ \text { lem 'plier' } & \text { lem-Is } & \text { 'deplier' } \\ \text { ray 'fermer' } & \text { ran-Is } & \text { 'ouvrir' (porte) } \\ \text { kUn 'fermer' } & \text { kUn-Is } & \text { 'ouvrir' (couvercle) }\end{array}$

To avoid the emergence of homophonous verb forms of the reversive and the repetetive, the Saafi dialect of Kirène developed the suffix sits for the repetetive.

${ }^{5} \mathrm{C}=$ homorganic consonant. 
The following tables provide comparative evidence of the vowel behaviour after the affixation of a high [+ATR] vowel. They contain examples for each vowel separately. As the causative and reversive derivation are not fully productive, the data is scarce. When undergoing regressive vowel assimilation the vowel $/ \mathrm{a} /$ is realised as a central vowel, [ə] or [e], in Palor:

(24) Regressive assimilation $[\mathrm{a}] \rightarrow[\mathrm{\partial}],[\mathrm{e}] /{ }_{-} \mathrm{i}$

\begin{tabular}{|c|c|c|c|}
\hline Basic form & Derived form & Function & Language \\
\hline 6ap 'suck' & 6әр-id' 'breastfeed' & $\mathrm{CS}$ & $\mathrm{Nd}$. \\
\hline 6ap 'suck' & bep-id' 'breastfeed' & $\mathrm{CS}$ & $\mathrm{P}$ \\
\hline bap 'suck' & bəp-id 'breastfeed' & $\mathrm{CS}$ & $\mathrm{L}$ \\
\hline bap 'suck' & bap-Id 'breastfeed' & CS & $\mathrm{S}$ \\
\hline nam 'eat' & nəm-id 'feed' & CS & $\mathrm{Nd}$ \\
\hline nam 'eat' & nem-id 'feed' & CS & $\mathrm{L}$ \\
\hline nam 'eat' & nəm-i? 'feed' & CS & $\mathrm{N}$ \\
\hline jan 'learn' & jog-i? 'teach' & CS & $\mathrm{N}$ \\
\hline jan 'learn' & jan-Id' 'teach' & CS & $\mathrm{S}$ \\
\hline jakat 'run' & jeket-id ${ }^{6}$ 'cause to run, drive' & CS & $P$ \\
\hline dap 'plug' & dəp-is 'unplug' & RV & $\mathrm{Nd}$ \\
\hline lan 'close' & lag-is 'open' & RV & $\mathrm{N}, \mathrm{L}$ \\
\hline ray 'close' & ray-is 'open' & $\mathrm{RV}$ & $\mathrm{S}$ \\
\hline laan 'put on the fire' & larg-is 'remove from the fire' & RV & $\mathrm{N}$ \\
\hline kal 'take' & kel-is 'throw away' & RV & $\mathrm{P}$ \\
\hline
\end{tabular}

There is variation in the output of the mid vowel [0] undergoing this process. In Noon and Laala the surface vowel [o] appears. In Ndut and Palor the counterpart is the central vowel $[\partial, \mathfrak{e}]$, although in the Ndut imperative paradigm the outcome of regressive harmony would be [o]. This variation could be explained as historical restructuring of regressive harmony. The causative and the reversive would represent an earlier stage of the language when the harmonic relations were lexically frozen. ${ }^{7}$ In contrast, the fully productive imperative suffixes appear to be an innovation that can only be found in Ndut and Palor.

${ }^{6}$ In this example from D'Alton (1987: 142) both preceding syllables are involved in the assimilation process. Probably, in $\mathrm{P}$ the domain of the assimilation is not restricted to the preceding syllable. Another possible interpretation of this phenomenon could be that rapid speech caused the progression of the assimilation.

${ }^{7}$ For this comment I have to thank once again David Odden. 
(25) Regressive assimilation $[0] \rightarrow[\mathrm{0}, \mathrm{k}],[\mathrm{o}] /{ }_{-} \mathrm{i}$

\begin{tabular}{|c|c|c|c|}
\hline Basic form & Derived form & \multicolumn{2}{|c|}{ Function Language } \\
\hline sos 'be/become cold' & səsid 'chill, cool' & $\mathrm{CS}$ & $\mathrm{Nd}$ \\
\hline soos 'be/become cold' & soos-id' 'chill, cool' & CS & $\mathrm{L}, \mathrm{N}, \mathrm{S}$ \\
\hline yoon 'learn' & yəəd-id' 'teach' & $\mathrm{CS}$ & $\mathrm{Nd}$ \\
\hline yoon 'learn' & yerd-id' 'teach' & $\mathrm{CS}$ & $P$ \\
\hline lom 'buy' & lom-id 'buy for s.o.' & $\mathrm{CS}$ & $\mathrm{N}$ \\
\hline pon 'fold' & pon-is 'unfold' & RV & $\mathrm{Nd}$ \\
\hline pon 'fold' & pon-is 'unfold' & RV & $\mathrm{L}$ \\
\hline k ‘tie’ & pek-is 'untie' & RV & $\mathrm{P}$ \\
\hline pok 'tie' & pok-is 'untie' & RV & $\mathrm{L}$ \\
\hline pok 'tie' & pak-is 'untie' & RV & $\mathrm{N}$ \\
\hline
\end{tabular}

The following table contains data for regressive harmony applying to the stem vowel $[\varepsilon]$ in Noon, Laala and Ndut. There is variation in the assimilation of the stem vowel $[\varepsilon]$ that may either result in [a] or [e] in Noon (cf. Soukka 2000: 162f.). This variation could plausibly be explained by attributing these vowels to different proto-phonemes $*[\mathrm{e}]$ and $*[\varepsilon]$. Rule (26) applies in the derived forms of (27).

(26) $\begin{aligned} \mathrm{e} & \rightarrow \mathrm{e} /{ }_{-\mathrm{i}}^{-\mathrm{i}} \\ \varepsilon & \rightarrow \text { o }{ }_{-\mathrm{i}}\end{aligned}$

(27) Regressive assimilation $[\varepsilon] \rightarrow[ə],[\mathrm{e}]$

Basic form Derived form

hej 'fight'

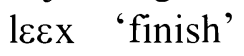

$1 \varepsilon \mathrm{m}$ 'ranger

à longueur'

secb 'pêcher'

pecn 'causer' hoj-is

'separa

leex-id 'finish something'

lem-is 'déranger'

seeb-id 'avoir pêché une fois'

peen-id
Function Language

$\mathrm{RV}$

$\mathrm{N}[: 163]$

CS

$\mathrm{N}[: 162]$

RV

$\mathrm{L}$

$\mathrm{Nd}$

$\mathrm{Nd}$

According to D'Alton (1987) the [-ATR] vowels [ $\varepsilon]$ and [0] have no [+ATR] counterpart in Palor. They behave neutrally if they follow a [+ATR] vowel. Preceding a high [+ATR] vowel, however, they evidence harmony and are altered to [i] and [ə] as a result of leftward vowel harmony. The unusual alternation of the mid vowel $[\varepsilon]$ with the high vowel [i] suggests that she has probably mistaken [i] for [e] which does not occur in her Palor vowel system: 
Les tendues peuvent être suivies, au sein du mot, par les voyelles /e/ [ع] et /o/ [o].

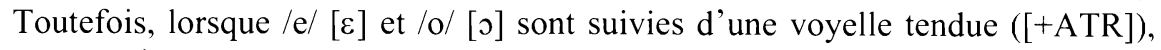
elles se réalisent respectivement /i/ et /ë/. [p. 93]

In (28), high [-ATR] vowels in Noon and Laala do not undergo regressive assimilation. This exclusion of high [-ATR] vowels from the assimilatory process might be an ancient phenomenon. As Noon and Laala are not closely related to Ndut the restriction of this phonological process to non-high vowels could even be reconstructed in the proto-language.

No regressive assimilation of the [-ATR] vowels /I/ [I] and /U/ [U]

Basic

form

nılk

yun

yun

tum

fin

yiln
Derived

form

nıık-i?
yug-i?
yud-i?
tum-i?
fly-i?
yılg-i?

$\begin{array}{ll}\text { 'frighten', } & \mathrm{CS} \\ \text { 'make sit' } & \mathrm{CS} \\ \text { 'teach' } & \mathrm{CS} \\ \text { 'make do' } & \mathrm{CS} \\ \text { 'make discard' } & \mathrm{CS} \\ \text { 'make smell, feel' CS }\end{array}$

$\mathrm{N}$

$\mathrm{CS} \quad \mathrm{N}$

CS L

CS L

CS L

LS

Similar cases of regressive vowel harmony can also be found in two neighbouring contact languages, Pulaar and Wolof. Both languages belong to the Senegambian subgroup of Atlantic languages. In Pulaar, regressive vowel assimilation leads to the emergence of [+ATR] mid vowels on the surface (Archangeli \& Pulleyblank 1994: 134). The Pulaar vowel system consists of five vowels [u, i, e, $o$, a], so [ATR] is not a contrastive feature in this system. Its values are completely predictible: a [+high] vowel is advanced and a [+low] vowel retracted. The tongue root values of the mid vowels are determined by the [ATR] property of the following vowel. High vowels imply [+ATR] on the preceding syllable. All non-high vowels imply [-ATR]. Thus, mid vowels exhibit an [ATR] contrast at the surface that "is entirely derivative and need not be reflected in underlying representations" (Archangeli \& Pulleyblank 1994: 137). Many verb derivation suffixes contain high vowels: among others, the reversive $-i t /$ - ut and the causative -in (cf. Arnott 1970: 334). 
An obviously cognate reversive suffix $-i$ triggering leftward vowel raising ${ }^{8}$ can also be found in Wolof (Ka 1994: 112). In the examples below either [-ATR] vowels become fronted without an alternation in their [ATR] value $(a \rightarrow \varepsilon)$, or they become raised and fronted $(a \rightarrow i)$.

(29)

$\begin{array}{llll}\text { samp 'to plant' } & \rightarrow & \text { semp-i } & \text { 'to take out' } \\ \text { takk 'to tie' } & \rightarrow & \text { tekk-i } & \text { 'to untie' } \\ \text { gəmm 'to close eyes' } & \rightarrow & \text { gimm-i } & \text { 'to open eyes' }\end{array}$

The common occurrence of the triggering reversive suffix in Fula. Wolof and Ndut could either be interpreted as an incidence of areal convergence or as common Atlantic inheritance. As the reversive derivation is lexically restricted to a few verbs it is unlikely to be borrowed. Thus, the reversive suffix containing the high vowel [i] appears to be a cognate suffix that might be reconstructed for Proto-Atlantic, if such a genetic unit existed.

\section{Progressive Vowel Harmony}

Progressive harmony ${ }^{9}$ occurs only in Ndut and Palor. The [ATR] property of the affix depends on the [ATR] property of the verb stem. A [+ATR] verb stem induces [+ATR] in the suffix vowel; a [-ATR] verb stem induces a [-ATR] vowel. Consequently, alternating suffixes appear. The following table (30) gives an overview of alternating suffixes in both languages without claiming to be exhaustive. The Palor data come from D'Alton (1987: 144).

${ }^{8}$ This process can be accompanied by the lengthening of the stem vowel and the gemination of the stem final consonants $\mathrm{Ka}(1994: 112)$.

${ }^{9}$ Hyman (2002: 10) claims that directionality of vowel harmony "is fully (or mostly) predictable based on one or more factors concerning the potential triggers and/or targets". In stemor root-controlled systems the root is the trigger and the affixes represent the target. Consequently, languages with suffixes exhibit rightward harmony whereas languages with prefixes have leftward harmony. As suffixation is more common than prefixation in languages it is supposed that there is a left-to-right bias in vowel harmony. 
(30) Alternating Suffixes in Ndut ${ }^{10}$ and Palor

\begin{tabular}{|c|c|c|}
\hline$N d u t$ & Function & Palor \\
\hline -id, -Id & 'benefactive' & -id, -Id \\
\hline -id & 'experiential' & -id, -Id \\
\hline -il,--1l & 'repetitive' & -il,-Il \\
\hline$-\mathrm{u},-\mathrm{U}$ & 'passive' & $-u,-u$ \\
\hline$-\varepsilon,-\mathrm{e}$ & $\begin{array}{l}\text { 'imperative singular' } \\
\text { 'achèvement de l'action' }\end{array}$ & $\begin{array}{l}-\varepsilon \\
-k ı n,-k i n\end{array}$ \\
\hline $\begin{array}{l}-\partial x,-\partial x \\
-\partial x,-\partial x\end{array}$ & $\begin{array}{l}\text { 'reciprocal' } \\
\text { 'agentive' }\end{array}$ & $-o x,-e x$ \\
\hline$-a ?,-ə ?$ & $\begin{array}{l}\text { 'transitive' } \\
\text { 'transitive' }\end{array}$ & $\begin{array}{l}-\mathrm{a} 2,-\mathrm{e} ? \\
-\mathrm{al},-\mathrm{el}\end{array}$ \\
\hline $\begin{array}{l}\text {-a?,-ə? } \\
\text {-ant-, -ənt- }\end{array}$ & $\begin{array}{l}\text { 'habitual' } \\
\text { 'reciprocal' } \\
\text { 'faire légérement' }\end{array}$ & $\begin{array}{l}\text {-an, en } \\
\text {-ante, -ente } \\
\text {-as, -es }\end{array}$ \\
\hline -aat, -əət & 'iterative' & \\
\hline
\end{tabular}

The suffixes - $A A t$ 'iterative', $-A l$ and -Ant 'reciprocal' appear to be borrowed from Wolof. Other suffixes share cognates with Noon and Laala. These cognate suffixes contain [-ATR] vowels such as $-U$ 'passive', $-\infty x$ 'pluractional' and the repetitive $-I S$ that corresponds to the alternating suffix $-I l$ in Ndut. ${ }^{11}$ When affixed to [+ATR] verb stems, no alternation occurs. Compare the following Laala and Noon verb stems containing high [+ATR] vowels. The Noon examples come from Soukka (2000):

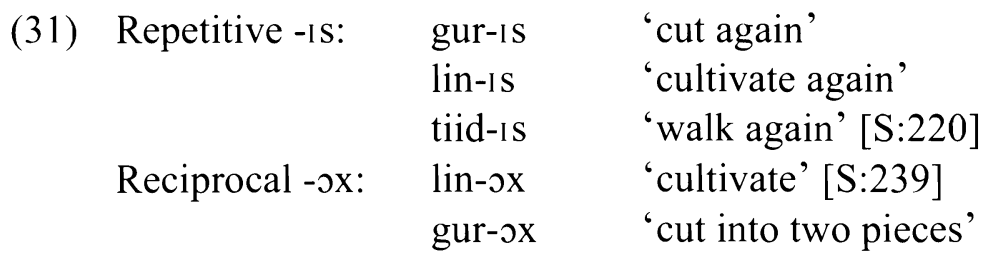

\footnotetext{
${ }^{10}$ Morgan (1996: 105) mentions additionally the following alternating suffixes: - $I d$ 'personal', -Is 'intensive', $-A d^{\prime}$ 'manner'.

${ }^{11}$ There are more examples to justify the regular sound correspondence $s \sim l$ : waas $(\mathrm{S}, \mathrm{N}, \mathrm{L}) \sim$ waal $(\mathrm{Nd}, \mathrm{P})$ 'chemin'; wos $(\mathrm{N}, \mathrm{L}) \sim$ wol $(\mathrm{Nd}, \mathrm{P})$ 'envoyer'; suusuus $(\mathrm{S}, \mathrm{N}, \mathrm{L}) \sim \operatorname{suul}(\mathrm{Nd}, \mathrm{P})$ 'noir'.
} 


$\begin{array}{lll}\text { Perfect -In: } & \text { yud-In } & \text { 'woken up' } \\ & \text { muy-In } & \text { 'got-lost' } \\ & \text { liif-in } & \text { 'got-full' } \\ & \text { pud-In } & \text { 'flown' } \\ & \text { dul-In } & \text { 'hit' } \\ & \text { kug-In } & \text { 'bent' [S:230] } \\ & \text { og-In } & \text { 'reddened' } \\ & \text { og-ir-in } & \text { 'made red' }\end{array}$

The alternating suffixes correspond to non-alternating suffixes with [-ATR] vowels in Noon and Laala. They contrast to non-alternating suffixes containing the triggering high [+ATR] vowels such as the reconstructed reversive $*_{-} i$ is and the causative $*_{-i d}$. These correspondences lead to the conclusion that suffixes with alternating vowels can be derived from underlying [-ATR] vowels. Alternating affixes in Nilotic languages exhibit a similar phonological development. Following the well-established principle of archaic heterogenity in morphological reconstruction, Dimmendaal (2002: 167) claims that these alternating affixes should be traced back into the proto-language as non-alternating suffixes with either inherently [+ATR] or [-ATR] vowels.

In Ndut and Palor, the definite article also follows the harmonic principles of the root. Nouns with [+ATR] vowels take the definite article $-\partial /-e$; nouns with [-ATR] vowels, the definite article $-a$. The definite article is preceded by one of the concord prefixes $\varnothing$-, $f$-, $k$-, $m$ - or $y$-.

(32) Alternating definite article -a/-o in Ndut

\begin{tabular}{|c|c|c|c|}
\hline \multirow{3}{*}{$\begin{array}{l}{[-\mathrm{ATR}]} \\
\text { af-a } \\
\text { loว?-a }\end{array}$} & & \multicolumn{2}{|l|}{ [+ATR $]$} \\
\hline & 'the head' & kəəm-ə & 'the public place' \\
\hline & 'the stomach' & & \\
\hline 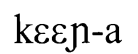 & 'the liver' & ner-a & 'the cloud' \\
\hline In-a & 'the village' & il-ə & 'the eye' \\
\hline kun-a & 'the finger' & pug-ə & 'the front' \\
\hline
\end{tabular}


(33) Alternating definite article in Palor (D'Alton 1987: 104)

$\begin{array}{llll}\text { [-ATR }] & & {[+ \text { ATR }]} & \\ \text { taan-a } & \text { 'l'oncle maternel' } & \text { penis-fe } & \text { 'le cheval' } \\ \text { ksj-a } & \text { 'l'ami' } & & \\ \text { yesg-a } & \text { 'le chant' } & & \\ \text { gin-a } & \text { 'le village' } & \text { yiin-e } & \text { 'la hâche' } \\ \text { xul-ya } & \text { 'les étoiles' } & \text { bug-e } & \text { 'la bouche' }\end{array}$

As the same alternation of the definite article can be found in the major contact language Wolof, the next claim will be that progressive harmony is a contact-induced innovation. To illustrate Wolof harmony, (34) presents alternating definite and demonstrative markers in Wolof (Ka 1994: 50). The direction of the spreading process is from left to right. Indefinite articles precede the noun and do not alternate. Definite articles and demonstratives occur after the noun. They alternate if they do not contain high vowels or the long low vowel:

(34) Alternating definite and demonstrative markers in Wolof (Ka 1994: 50)

\begin{tabular}{|c|c|c|c|}
\hline [+ATR $]$ & $\operatorname{gloss}^{12}$ & [-ATR] & gloss \\
\hline ab jigeen & a woman & ab xale & a child \\
\hline geen $\mathrm{ji}$ & the woman (close) & xale bi & the child (close) \\
\hline geen jə & the woman (away) & $\mathrm{xal} \varepsilon$ ba & the child (away \\
\hline en jəle & that woman & xale bale & that child \\
\hline een jee & that woman & 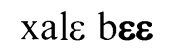 & that child \\
\hline
\end{tabular}

The correspondence of the alternating definite articles $-\partial /-a$ in both languages is evident. The other Cangin languages Noon and Laala exhibit alternation of either of the definite articles $-I I$ (proximal) or $-a a$ (distal). Compare the following [+ATR] noun stems of Laala: xuul-aa 'the Palmyra palm', niin-aa 'the ant', lup$a a$ 'the sting', tin- $a a$ 'the headpad'. The sound correspondence of the distal definite article $-a a$ in Noon and Laala with the alternating definite article $-\partial /-a$ in Ndut could imply the common origin of both markers. But even in that case, the possiblity of contact-induced emergence of progressive harmony in Ndut and Palor can not entirely be excluded.

The intense language contact with Wolof is further indicated by other structural borrowings such as the plural class marker and the demonstrative. In

\footnotetext{
${ }^{12}$ For many demonstratives in Wolof it is impossible to find an appropriate translation into English.
} 
Ndut and Palor there is only one plural class marker $y$ - that corresponds formally and functionally to the overall plural class marker $y$ - in Wolof. The overall plural class markers for the majority of nouns in the other Cangin languages is $c$-. In Saafi, this is the only class marker for plural nouns. Only Noon and Laala exhibit another remnant plural class $t$ - which contains just a few nouns.

Whereas the definite article in Ndut obligatorily takes a class concord prefix, demonstratives exhibit only a number distinction. All singular nouns invariably take the demonstrative concord $b$-. For plural nouns the demonstrative concord is $y$ - Comparison with demonstratives of the other Cangin languages demonstrates that the borrowing of these prefixes from Wolof is the most plausible explanation for their occurrence in Ndut and Palor. The following table represents the different demonstratives and their concord prefixes.

Comparison of demonstratives

$\begin{array}{lllllll}\text { Demonstrative } & \text { Ndut } & \text { Palor } & \text { Saafi } & \text { Laala } & \text { Noon } & \text { Wolof } \\ \text { proximal } & -\varepsilon(\mathrm{x}) & -\varepsilon \varepsilon & -\mathrm{ii} & -\mathrm{ii} & -\mathrm{ii} & -\mathrm{ii} /-\mathrm{il} \varepsilon \\ \text { medial } & -\mathrm{a} & -\mathrm{in} & -\mathrm{um} & -\mathrm{aa} & -\mathrm{aa} & -\mathrm{ee} /-\mathrm{al} \varepsilon \\ \text { distal } & -\mathrm{In} & -\mathrm{in}-\mathrm{in} & -\varepsilon \mathrm{n} & -\mathrm{uuni} & -\mathrm{uu}-\mathrm{n} \varepsilon \varepsilon & \\ \text { concord } & \mathrm{b}-(\mathrm{sg}) & \mathrm{b}-(\mathrm{sg}) & \varnothing-(\mathrm{sg}) & \varnothing-, \mathrm{f}- & \varnothing-, \mathrm{f}- & \mathrm{b}-, \mathrm{k}-(\mathrm{sg}) \\ & \mathrm{y}-(\mathrm{pl}) & \mathrm{j}-(\mathrm{pl}) & \mathrm{c}-(\mathrm{pl}) & \mathrm{c}-, \mathrm{t}- & \mathrm{c}-, \mathrm{t}- & \mathrm{y}-, \mathrm{n}-(\mathrm{pl})\end{array}$

In Wolof, the class concord system consists of two major concord classes, with the prefixes $b$-for singular and $y$-for plural and a few remnant concord classes. Thus, most demonstratives in Wolof take either the concord prefix $b$ - for singular nouns or $y$-for plural nouns. In Saafi, demonstratives exhibit only a number distinction, but the prefixes can be deduced from the concord prefixes $\varnothing$ - for the singular and $c$ - for the plural. In Noon and Laala, languages with more elaborate concord systems, there is a greater variety of concord markers for the demonstratives: six singular concord prefixes $\varnothing-, f_{-}, m_{-}, k-, p-, j$ - and two plural concord prefixes $c$ - and $t$-. But even in these languages, the majority of nouns are assigned either to class $\varnothing$-in the singular or to class $c$ - in the plural.

A phonological comparison of Wolof and Ndut reveals major differences in the vowel inventory and the mechanisms of the harmony systems. According to Ka (1994: 11), Wolof distinguishes eight vowels that can be either long or short, except for the central vowel [ə] which can only be a short vowel. The [+ATR] vowels outnumber the [-ATR] vowels and there is no contrast between high [+ATR] and [-ATR] vowels. 
(36) Wolof vowels
[+ATR]
$[-\mathrm{ATR}]$
i, ii
[+ATR]
$[-\mathrm{ATR}]$
$\mathrm{u}, \mathrm{uu}$
i, ii
I, II
e, ee
$\varepsilon, \varepsilon \varepsilon$
$\mathrm{u}, \mathrm{uu}$
$\mathrm{U}, \mathrm{UU}$
o, oo
$\supset$, ว०
e, ee
$\varepsilon, \varepsilon \varepsilon$
ə
a, aa
ว, วอ
$\partial$, ว
a, aa

Ndut vowels

The Ndut vowel system appears to be more symmetrical than the Wolof system. Almost every [+ATR] vowel has a [-ATR] vowel as a counterpart, except for the mid vowel $\supset$ which shares the central vowel as [+ATR] counterpart with the low vowel $a$ as shown above. In Wolof, the high vowels are always [+ATR] and the long low vowel aa has no long [+ATR] counterpart.

Wolof vowel harmony can briefly be described as follows: within a word, vowels usually agree for [ATR] except for the two high vowels and the long low vowel which are the vowels missing a [-ATR] or [+ATR] counterpart. The direction of the spreading process is from right to left or from the root to the suffix, as the functional load of Wolof is primarily expressed by suffixes or postpositional elements such as the definite markers shown above.

Rightward harmony is also attested within verb derivation. Suffixes containing mid or short low vowels do alternate. Non-alternating suffixes contain either high vowels or the long low vowel. The agentive suffix -kat does not alternate either.

(37) Alternating and Non-alternating Suffixes in Wolof (Ka 1994: 13)

\begin{tabular}{|c|c|c|c|}
\hline $\begin{array}{l}\text { Alternating } \\
\text { suffixes }\end{array}$ & Meaning & $\begin{array}{l}\text { Non-alternating } \\
\text { suffixes }\end{array}$ & Meaning \\
\hline$-e /-\varepsilon$ & $\begin{array}{l}\text { 'instrumental } \\
\text { locative' }\end{array}$ & $-i$ & 'reversive' \\
\hline$-\mathrm{le} /-\mathrm{l} \varepsilon$ & 'participant' & $-\mathrm{i}$ & 'motion away' \\
\hline$-\mathrm{te} /-\mathrm{t} \varepsilon$ & $\begin{array}{l}\text { 'physical or } \\
\text { moral state' }\end{array}$ & -in & 'manner' \\
\hline$-e e /-\varepsilon \varepsilon$ & $\begin{array}{l}\text { 'temporal } \\
\text { conditional' }\end{array}$ & -it & 'residual' \\
\hline$-e e l /-\varepsilon \varepsilon l$ & 'conceptual' & $-\mathrm{si}$ & 'motion towards' \\
\hline -leen/-lecn & $\begin{array}{l}\text { '2 pl. } \\
\text { imperative' }\end{array}$ & $-\mathrm{u}$ & $\begin{array}{l}\text { 'reflexive- } \\
\text { neutropassive }\end{array}$ \\
\hline$-0 /-0$ & 'nominalizing' & -ukaay & 'instrumental' \\
\hline
\end{tabular}




\begin{tabular}{|c|c|c|c|}
\hline$-00 /-00$ & 'reciprocal' & $-1 \mathrm{u}$ & 'benefactive' \\
\hline -oon/ -oon & 'past tense' & -aan & 'transitional' \\
\hline -əm/-am & '3 sg. possessive' & -aat & 'iterative' \\
\hline- -əl/-al & 'benefactive' & -aay & 'quality' \\
\hline$-\partial t /-a t$ & 'intensive' & -aale & 'associative' \\
\hline -əndoo / -and & 'comitative' & -aange & 'result' \\
\hline -ənte / ant & 'mutual' & $-k a t$ & 'agentive' \\
\hline -ənde / -and $\varepsilon$ & 'moral quality' & & \\
\hline -ənti / -anti & 'corrective' & & \\
\hline -əli/ -ali & 'completion' & & \\
\hline -əndi /-andi & 'partial' & & \\
\hline -ədi / -adi & 'depriving' & & \\
\hline -əntu / antu & 'depreciative' & & \\
\hline
\end{tabular}

When comparing Wolof and Ndut vowel harmony, three major differences can be found. First, in Ndut there are suffixes with alternating high vowels shown in (30). Second, the [-ATR] back mid vowel [0] may have the central vowel [ə] as [+ATR] counterpart, which it shares with the low vowel [a]. Third, there are alternating suffixes with the long low vowel such as the iterative suffix -aat. Interestingly, this suffix is borrowed from Wolof and has developed a long [+ATR] counterpart -əət in Ndut. In Wolof, the same suffix does not alternate because it contains a long low vowel that lacks a $[+$ ATR $]$ counterpart in the vowel system.

(38) Alternating iterative suffix -aat/-azt in Ndut:

$\begin{array}{llll}\text { [+ATR]: } & \text { kun 'close' } & \text { kunəət } & \text { 'close again' } \\ \text { [-ATR]: } & \text { pon 'fold' } & \text { ponat } & \text { 'fold again' }\end{array}$

Archangeli and Pulleyblank (1994: 225) claim that in Wolof vowel harmony [-ATR] or [RTR], retracted tongue root, is the active feature element that triggers harmony and not the advanced tongue root [+ATR]. In Ndut vowel harmony, however, the active feature element appears to be [+ATR]. Diachronically, all the alternating suffixes can be derived from non-alternating suffixes with [-ATR] vowels. Thus, [+ATR] stem vowels trigger the vowel alternation in suffixes. In his comparative study of vowel harmony systems Casali (2003) claims that [ATR] dominance depends on the structure of the vowel inventory. Two underlying vowel inventory types with contrastive [ATR] dominance can be distinguished: 
[+ATR] is dominant in languages with an [ATR] contrast among high vowels.

[-ATR] is dominant in languages with an [ATR] contrast among nonhigh vowels.

The Ndut vowel system corresponds exactly to the first type vowel inventory. [ATR] is contrastive for high vowels and [+ATR] is the dominant harmonic feature. The second type inventory is represented by the Wolof vowel system. Only non-high vowels exhibit an [ATR] contrast and the dominant feature of the harmony is claimed to be [-ATR]. According to this analysis the harmonies of both languages share only the spreading direction from left to right but involve different vowels. The borrowing process would thus have included the adaptation of the harmonic features to the vowel system of the borrowing language.

\section{Conclusion}

This paper attempts a diachronic analysis of two different phonological processes in Ndut: regressive and progressive harmony. Comparative evidence suggests that regressive harmony is an ancient phenomenon that can be traced back to the proto-language and probably even beyond. The occurrence of progressive harmony is restricted to Ndut and Palor and to the major contact language Wolof. The other Cangin languages as well as the other Senegambian languages Fula and Seereer that are spoken in the neighbourhood do not exhibit progressive harmony. The occurrence of other structural borrowings from Wolof support the claim that progressive harmony is a contact-induced innovation in Ndut. However, historical sources to document the intense language contact between Ndut/Palor and Wolof are lacking. Only a look at the geographical location of the Cangin speakers may give an idea of the sociolinguistic setting at the moment of borrowing. The settlements of both Ndut and Palor speakers are scattered along two main roads, where different ethnic groups are settling, many of whom are traders. In contrast, Noon and Laala villages are situated in more remote locations. These ethnic populations are almost homogeneous, and they subsist primarily on agriculture.

Vowel harmony as a contact-induced phenomenon is still not very well investigated, but probably is not as uncommon as assumed. A similar case of borrowing is attested in the Western Chadic language Tangale, which has apparently borrowed its vowel harmony from the Adamawa language Waja (Kleinewillinghöfer 1990). Dimmendaal (2001: 370) discusses the possibility of vowel harmony being an ancient convergence phenomenon in Niger-Congo and clearly 
demonstrates that the occurrence of vowel harmony is restricted to several geographic areas that do not correspond to the genetic boundaries of the languages.

Thomason and Kaufman (1988: 53) discuss the borrowing of vowel harmony as a case of heavy structural borrowing that may result in a complete language shift or even language death. In Asia Minor Greek, strong Turkish influence resulted in the borrowing of Turkish vowel harmony and other linguistic features. This leads us to wonder whether contact-induced language shift is likely to occur in Ndut. Ndut is spoken in the villages around Mont Rolland. The local population still uses Ndut for their everyday conversations, and children are still learning the language. These facts imply that the language is far from dying in the countryside. In bigger towns, Ndut does not play any important role. The dominant language of urban society is Wolof since it is Senegal's most important means of interethnic communication. However, today many varieties of urban Wolof, widely spoken as a second language by speakers with different linguistic backgrounds, have lost their vowel harmony; the alternating definite article changes to non-alternating $a$. This is the only form of the distant definite article present in the Wolof-French dictionnary of Fal, Santos and Doneux (1990). Thus, the harmonic concept must have been borrowed at an earlier time, when vowel harmony in Wolof was still active. This fact points to a period of stable bilingualism of Ndut and Wolof, since the moment of the heavy structural borrowing of vowel harmony persisting until today.

\section{APPENDIX}

The following comparative wordlists contain the vowels /a, aa, u, uu, i, ii/ in cognates of the Cangin languages. The high vowels of Saafi are marked with majuscule letters I and U because of the lack of [ATR] contrast between high vowels.

Set 1: Short vowel /a/

$\begin{array}{llllll}\text { Ndut } & \text { Palor } & \text { Saafi } & \text { Laala } & \text { Noon } & \\ \text { xas } & \text { xas } & \text { as } & \text { as } & \text { as } & \text { 'new' } \\ \text { xay } & \text { xay } & \text { an } & \text { an } & \text { an } & \text { 'large' } \\ \text { ana } & \text { ana } & \text { kanak } & \text { ka-nak } & \text {-anak } & \text { 'two' } \\ \text { jam } & \text { nam } & \text { nam } & \text {-nam } & \text {-nam } & \text { 'eat' } \\ \text { xan } & \text { xan } & \text { an } & \text {-an } & \text {-an } & \text { 'drink' } \\ \text { xap } & \text { xap } & \text { ap } & \text {-ap } & \text {-ap } & \text { 'kill' }\end{array}$


Set 2: Long vowel /a:/

$\begin{array}{llllll}\text { Ndut } & \text { Palor } & \text { Saafi } & \text { Laala } & \text { Noon } & \\ \text { naa? } & \text { na? } & \text { yanaw } & \text { yaanaw } & \text { yaanaaw } & \text { 'white' } \\ \text { waal } & \text { waal } & \text { waas } & \text { waas } & \text { waas } & \text { 'way' } \\ \text { baa6 } & \text { baa6 } & \text { baa6 } & \text {-baaw } & & \text { 'travel' } \\ \text { yaal } & \text { yaal } & \text { yaar } & \text { yaal } & \text { yaal } & \text { 'man, } \\ & & & & & \text { husband' }\end{array}$

Set 3: Short vowel /u/

$\begin{array}{llllll}\text { Ndut } & \text { Palor } & \text { Saafi } & \text { Laala } & \text { Noon } & \\ \text { pun } & \text { pun } & \text { pUn } & \text {-pun } & \text {-pun } & \text { 'fly' } \\ \text { buk } & \text { buk } & \text { nkUp } & \text { kuu } & \text { kuu6 } & \text { 'mouth' } \\ \text { gumu } & \text { gumu? } & \text { ngUmU } & \text { gumu } & & \text { 'hyena' } \\ \text { luk } & \text { luk } & \text { (kose) } & \text { (kose?) } & \text { luk } & \text { 'tail' } \\ \text { sux } & \text { su? } & \text { sU/sUdI } & \text { suw-in } & \text { su6 } & \text { 'dry' } \\ \text { fulil } & \text { fulil } & \text { fUdIs } & \text {-furls } & \text {-furis } & \text { 'blow' } \\ \text { mun } & \text { mun } & \text { mUn } & \text { mun } & \text { muun } & \text { 'flour, } \\ & & & & & \text { powder' }\end{array}$

Set 4: Long vowel /u:/

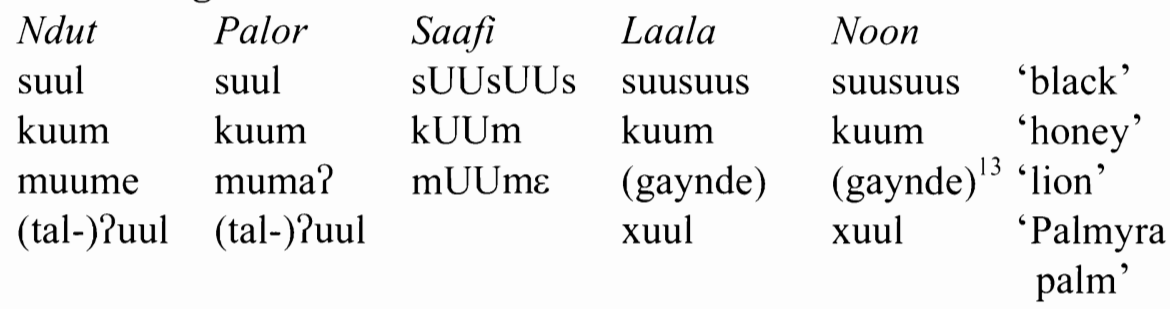

Set 5: Short vowel /i/

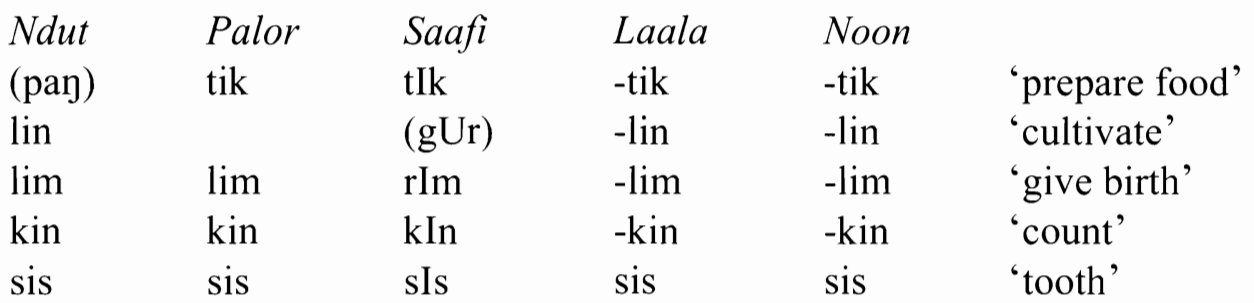


Set 6: Long vowel /i:/

$\begin{array}{llllll}\text { Ndut } & \text { Palor } & \text { Saafi } & \text { Laala } & \text { Noon } & \\ \text { niil } & \text { niil } & \text { nIIr } & \text { niil } & & \text { 'root' } \\ \text { til } & \text { tiil } & \text { tIIn } & \text {-tiin } & \text {-tiin } & \text { 'walk' } \\ \text { 6iib } & \text { biip } & \text { 6IIp } & \text { 6iiw } & \text { 6iib } & \text { 'breast' } \\ \text { jiin } & \text { jiin } & \text { kInIn } & \text { (kumun) } & \text { (kumun) } & \text { 'nose' }\end{array}$

\section{REFERENCES}

Archangeli, Diana \& Douglas Pulleyblank. 1994. Grounded Phonology. Cambridge Massachusetts: MIT Press.

Arnott, David W. 1970. The Nominal and Verbal System of Fula. London, Oxford: Clarendon Press.

Casali, Roderic F. 2003. "[ATR] value asymmetries and underlying vowel inventory structure in Niger-Congo and Nilo-Saharan". Linguistic Typology 7: 307-382.

Clement, George N. 2000. "Phonology". African Languages. An Introduction, ed. by Bernd Heine. Cambridge: Cambridge University Press. Pp. 123 - 160.

Crowley, Terry. 1994. An Introduction to Historical Linguistics. Auckland: Oxford University Press.

D’Alton, Paula. 1987. Le Palor. Esquisse phonologique et grammaticale d'une langue cangin du Sénégal. Paris: Edition du CNRS.

Diop Diagne, Maleine. 1989. Aperçu comparatif et synchronique des systèmes phonologiques et nominaux des langues cangin. Paris: Université de la Sorbonne nouvelle, Mémoire de Maîtrise 
Dimmendaal, Gerrit. 2001. "Language diffusion versus genetic inheritance: an African perspective". Areal Diffusion and Genetic Inheritance ed. by Alexandra Aikhenvald \& R. M. W. Dixon. Oxford: Oxford University Press. Pp. 358392.

Dimmendaal, Gerrit. 2002. "Constraining disharmony in Nilotic: what does an optimal system look like?" Journal of African Languages and Linguistics 23: 153-181.

Fal, Arame, Rosine Santos \& Jean-Leonce Doneux. 1990. Dictionnaire WolofFrançais. Paris: Karthala.

Hyman, Larry. 2002. "Is there a left-to-right bias in vowel harmony?". Paper presented at the 9th international phonology meeting in Vienna, Nov. 1 2002. To appear in the proceedings (Phonologica).

Ka, Omar. 1994. Wolof Phonology and Morphology. Lanham: University Press of America.

Kleinewillinghöfer, Ulrich. 1990. "Aspects of vowel harmony in Waja and Tangale-Waja common vocabulary". Frankfurter Afrikanistische Blätter 2: 93106.

Morgan, Daniel Ray. 1996. Overview of Grammatical Structures of Ndut, a Cangin language of Senegal. Arlington: University of Texas, M.A. Thesis.

Sapir, J. David. 1971. "West Atlantic: an inventory of the languages, their noun class systems and consonant alternation". Current Trends in Linguistics. Vol. 7. Linguistics in Sub-Saharan Africa ed. by Thomas Sebeok. Paris and The Hague: Mouton. Pp. 45-112.

Soukka, Maria. 2000. A Descriptive Grammar of Noon. München: Lincom Europa.

Stewart, John M. 1983. "Akan vowel harmony: the word structure condition and the floating vowels. Studies in African Linguistics 14: 111-139. 
Thomason, Sarah \& Terrence Kaufman. 1988. Language Contact, Creolization and Genetic Linguistics. Berkeley, Los Angeles/Oxford: University of California Press.

Williams, Gordon. 1994. "Intelligibility and language boundaries among the Cangin peoples of Senegal". Journal of West African Languages 24.1: 47-67.

Institute of African Linguistics

Meister-Ekkehart-Str. 7

University of Cologne

Cologne, Germany

udrolc@gmx.de [received December 20, 2003

accepted September 17, 2004] 
